\title{
A new species of Brachyorrhos from Seram, Indonesia and notes on fangless homalopsids (Squamata, Serpentes)
}

\author{
John C. Murphy ${ }^{1,2^{*}}$ and Harold K. Voris ${ }^{1}$
}

\begin{abstract}
Homalopsid snakes are monophyletic and contain two major subclades: a fangless clade and rear-fanged clade. They are distributed in South Asia, Australasia, and the Western Pacific. The fangless clade is restricted to the eastern Indonesian Archipelago and the island of Sumatra and is poorly known in terms of its natural history. Molecular data support the eastern Indonesian fangless endemic genus Brachyorrhos as the sister to the rear-fang clade. Here we recognize the identity of the Brachyorrhos population from the island of Morotai as B. wallacei and describe a new species of dwarf Brachyorrhos from the island of Seram, Malukus, Indonesia. The new species can be distinguished from all congeners by a lower number of ventral scales, the presence of a preocular scale and a loreal scale, as well as its exceptionally diminutive size. The new species is a candidate for the smallest alethinophidian snake. The three fangless genera, Brachyorrhos, Calamophis, and Karnsophis, have been suggested to form a clade of homalopsid snakes restricted to the Indonesian Archipelago, and we discuss their biogeography.
\end{abstract}

Keywords: biogeography, Calamophis, Homalopsidae, Karnsophis, small snakes

\section{Introduction}

Snakes in numerous lineages show specializations for fossoriality. Morphological trends associated with burrowing include the loss or fusion of cephalic scales, a reduction in the number of dorsal scale rows, modifications of the premaxillary bone, and abbreviation of the tail (Savitzky 1983). Fossorial snakes also have constraints on the head's width because it influences the snake's ability to penetrate the substrate and exposes cranial bones to the physical stress of burrowing. Also associated with fossorial specializations are small size and a reduced number of ventral scales (Inger \& Marx 1965). An analysis of snakes from biogeographic realms found $27.8 \%$ in the Oriental region were fossorial and suggests that fossorial snakes of all lineages are likely to be among the most derived (Rabb \& Marx 1973).

The eastern Indonesian homalopsid snake genus Brachyorrhos Kuhl in Schlegel, 1826 is endemic to the

${ }^{1}$ Science \& Education, Field Museum, 1400 S Lake Shore Dr, Chicago, IL 60605 U.S.A.

${ }^{2}$ Current Address: 2564 E Murdoch Ct., Green Valley, AZ 85614 U.S.A.

*Corresponding email: serpentresearch@gmail.com

Date Submitted: 15 December 2019

Date Accepted: 27 May 2020
Malukus Islands of eastern Indonesia and represents a fangless, vermivorous clade of otherwise mostly rear-fanged, piscivorous snakes.

In a review of the genus Brachyorrhos, Murphy et al. (2012) found B. albus (Linnaeus, 1758) occurs on Seram, Ambon, and nearby satellite islands in the Seram Island group. They removed Rabdion gastrotaenia Bleeker, 1860 from the synonymy of Brachyorrhos albus (on Buru Island) and Atractocephalus raffrayi Sauvage, 1878 (1879) was resurrected for the Brachyorrhos species (on Ternate Island); they also described a new species from Halmahera, B. wallacei Murphy, Mumpuni, de Lang, Gower, \& Sanders, 2012. Additionally, they removed Calamophis Meyer, 1874 from the synonymy of Brachyorrhos. Figure 1 illustrates the distribution of the three fangless genera, two from West Papua, and one from Sumatra, Karnsophis siantaris Murphy \& Voris, 2013. Together, these three genera likely form a fangless clade of basal homalopsids (Murphy \& Voris 2014). The genera Karnsophis and Calamophis were tentatively assigned to the Homalopsidae based upon their morphological similarities to Brachyorrhos. To date, only Brachyorrhos has been included in phylogenetic analyses using molecular data.

Here we describe a novel species of Brachyorrhos and discuss the biogeography of the fangless homalopsids. Brachyorrhos contains small ( $<74 \mathrm{~cm}$ total length) snakes with 19 scale rows at the mid and posterior body and relatively short tails (7.5-18\% of the SVL). Most specimens have the prefrontal, 


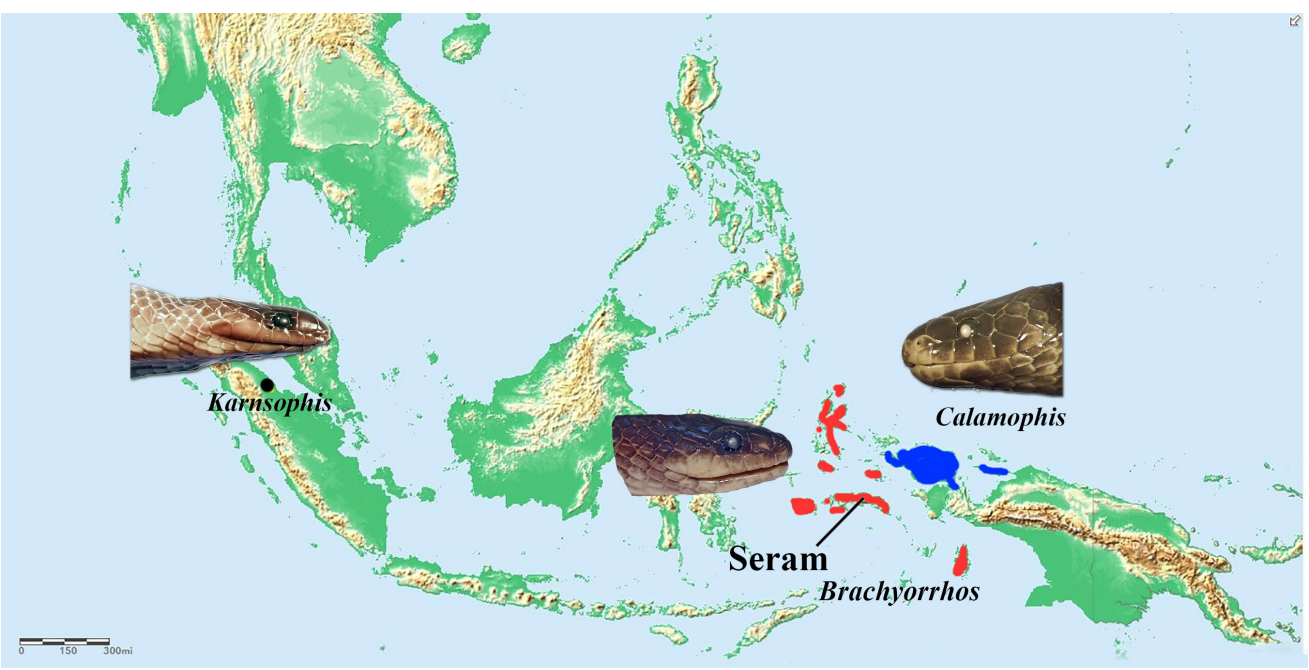

Figure 1. Distribution of the fangless homalopsids. Karnsophis siantaris (upper left), Brachyorrhos albus (center), Calamophis sharonbrooksae (right).

loreal, and preocular fused, some have a single postocular and this is diagnostic in at least two taxa. Although some species show a pattern of head and nape markings (these are most often present in neonates and juveniles), and a mid-ventral stripe, most specimens have a uniform brown to brown-black dorsum and a yellow or cream venter. All Brachyorrhos have a divided internasal, and none show a posterior reduction in dorsal scales anterior to the cloacal plate.

The goals of this paper are to resolve two issues that remained after the publication of Murphy et al. (2012). First, we describe a novel species of Brachyorrhos from the island of Seram based on a single specimen collected in 1909. The specimen is morphologically divergent from other Brachyorrhos in its low ventral count, the presence of a loreal, and its exceptionally small size. Secondly, a specimen of Brachyorrhos from the island of Morotai, is reported here for the first time. Morotai is one of the northernmost islands in the Halmahera group of the Malukus and is about $470 \mathrm{~km}$ southeast of Mindanao in the Philippines. No snakes in the genus Brachyorrhos have been previously described from Morotai.

\section{Materials and Methods}

Museum specimens of Brachyorrhos were examined, and external morphological data were collected for 64 museum specimens (Appendix 1). Measurements of body and tail lengths were taken to the nearest $1 \mathrm{~mm}$ with a meter stick; ventral scales were counted following Dowling (1951). The terminal scute was not included in the number of subcaudals. Dorsal scale row counts were made about ten ventrals behind the head, at mid-body, and about ten ventrals anterior to the vent. Scale nomenclature follows Lillywhite (2008). Values for paired head scales and subcaudals are given in left/right order. A principal component analysis (PCA) was done with Excel (2019, v16) with Xlstats (2020.1). The PCA used 33 Brachyorrhos specimens representing all known species of the genus including the new species described here. Data collected included: ventral scale counts, subcaudal scale counts, preocular presence or absence, number of upper labials, tallest upper labial, number of lower labials, presence, or absence of a loreal. The variables, eigenvalues and factor correlations are given in Appendix 2.

Abbreviations are: MY - millions of years; MYA - millions of years ago; $\mathrm{N}$ - number of specimens; $\overline{\mathrm{x}}$ - mean value; SVL snout vent length; SD - standard deviation; PLP - prefrontalloreal-preocular scales fused together.

\section{Results}

Since the publication of Murphy et al. (2012) we had the opportunity to examine additional specimens and consider some unresolved problems posed by a specimen examined during the review of Brachyorrhos. The results are divided into two sections, the new species of Brachyorrhos from Seram, and the identity of the specimen from Morotai. While examining specimens of Brachyorrhos at the Natural History Museum (NHM), formerly the BMNH, one of us (JCM) collected data on a small Brachyorrhos (BMNH 1910.4.26.60) that Samuel McDowell had previously examined. The museum's catalog contained the following paragraph in the form of a hand-written note concerning the specimen collected in 1909 on Seram by Wilfred Stalker. 
This snake has ca. 40 ventrals too few, lacks any trace of a tracheal lung, has no bar of bone ventral to nerve V2 to define a foramen for that nerve in the palatine, and has mature ovarian eggs although with a colour pattern suggestive of a juvenile. It has posterior hypapophyses and seems referable to Brachyorrhos. But Ceram B. albus are similar to your Ternate specimens as least to judge from AMNH specimens. I have seen one specimen approaching this, a male from the Vogelkop (Bishop Mus.) and I suspect this specimen is a Ceram record for Brachyorrhos jobiensis.

Sam McDowell, 18 July 1978

Examination suggested that it was a Brachyorrhos. It has 19 dorsal scale rows that were not reduced posteriorly, a head scale arrangement mostly consistent with Brachyorrhos, and a color pattern similar to that seen in juvenile Brachyorrhos. The specimen shares two postoculars; one preocular; a fused loreal and prefrontal; upper labials $7 / 6$, the fourth bordering the orbit; four lower labials contacting the chin shields; two internasals; and 19 dorsal scale rows that are not reduced posteriorly with most other species of Brachyorrhos. McDowell (1987) associated the small size and the low ventral scale count with Calamophis jobiensis (Meyer, 1874) which prompted him to suggest the specimen was Brachyorrhos jobiensis Meyer, 1874. Calamophis had been placed in the synonymy of Brachyorrhos by Peters \& Doria (1878). Later, McDowell (1987) wrote that Brachyorrhos would be a homalopsid if they had fangs. A molecular study (Murphy et al. 2011) later confirmed Brachyorrhos was in the family Homalopsidae and the sister to all other homalopsid snakes.

Little is known about the collector of BMNH 1910.4.26.60, British naturalist and bird collector Wilfred Stalker. Stalker made a trip to central Seram in 1909 where he assembled a "remarkable zoological collection." (Anon. 1910:436) BMNH 1910.4.26.60 was part of that collection. Stalker was preparing for the British Ornithologists' Union's collecting trip to New Guinea and he met the other members of the expedition in Amboina on January 1, 1910. Eight days later he drowned (Anon. 1910; Wollaston 1912). Stalker collected many bird specimens that later became holotypes (LeCroy, 2003; Lily, 2008) evidence that his collections were made in localities not previously investigated by zoologists.

We included BMNH1910.4.26.60 in a principal component analysis (Fig. 2 and Appendix 2) and found it similar to other Brachyorrhos in morphospace but it stands alone because of its distinctive morphology (a preocular, a loreal, and a low ventral count). Brachyorrhos are the only homalopsid snakes known to have bilobed nasal scales separated by the rostral; a divided internasal positioned

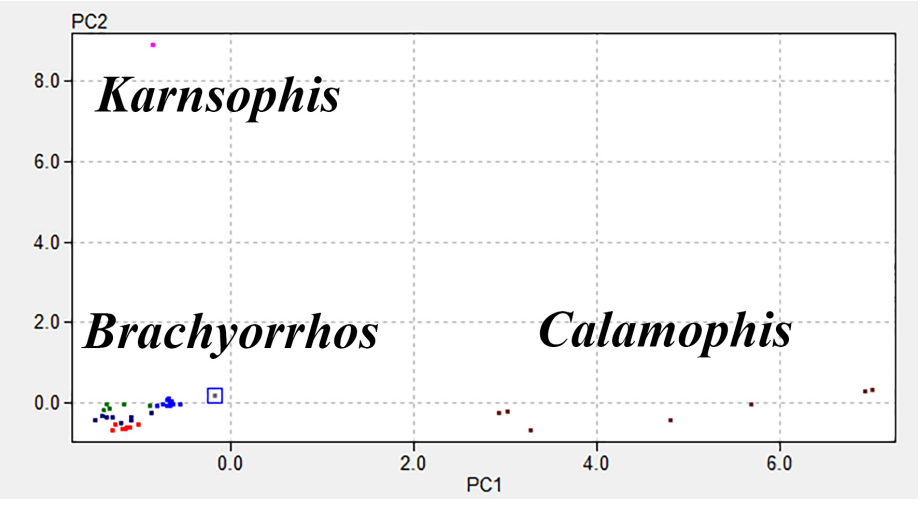

Figure 2. Results of a principal component analysis. Details in Appendix 2.

posterior and dorsal to the nasals. Brachyorrhos is distinguished from Calamophis by the lack of a reduction in dorsal scale rows (Brachyorrhos has 19-19-19, Calamophis has 19-19-17). Brachyorrhos has dorsal scales that are ovate, slightly imbricate or juxtaposed compared to the distinct imbricate dorsal scales in Calamophis, Brachyorrhos has a divided nasal scale, and a tail that lacks a constriction at its base and tapers gradually to the tip. Given the morphological evidence we describe $\mathrm{BMNH}$ 1910.4.26.60 below as the fifth species in the genus Brachyorrhos.

\section{Taxonomic Results}

\section{Brachyorrhos pygmaeus species nova}

Figure 3

Holotype: BMNH1910.4.26.60, a mature female from Seram Island, Malukus, Indonesia collected in 1909 by Wilfred Stalker.

\section{Type Locality: Seram Island.}

Diagnosis. A Brachyorrhos with a rounded snout, a loreal scale; one preocular scale; upper labials six or seven, the fourth upper labial bordering the orbit; the second and third upper labials contact loreal; six lower labials; 143 ventral scales; 22 subcaudal scales; the tail is $11.5 \%$ of the SVL.

Description of Holotype: a mature female with a total length of $128 \mathrm{~mm}$ : tail $13 \mathrm{~mm}$. Rostral slightly visible from above; snout rounded; nasals bilobed with posterior lobe penetrating the seam between the prefrontal and second upper labial, and separated by two internasals. Frontal pentagonal, shorter than parietals; two prefrontals contact loreals on each side; preocular single; postoculars two; primary temporal single; seven upper labials on the left and six on the right, loreal contacts second and third, the 

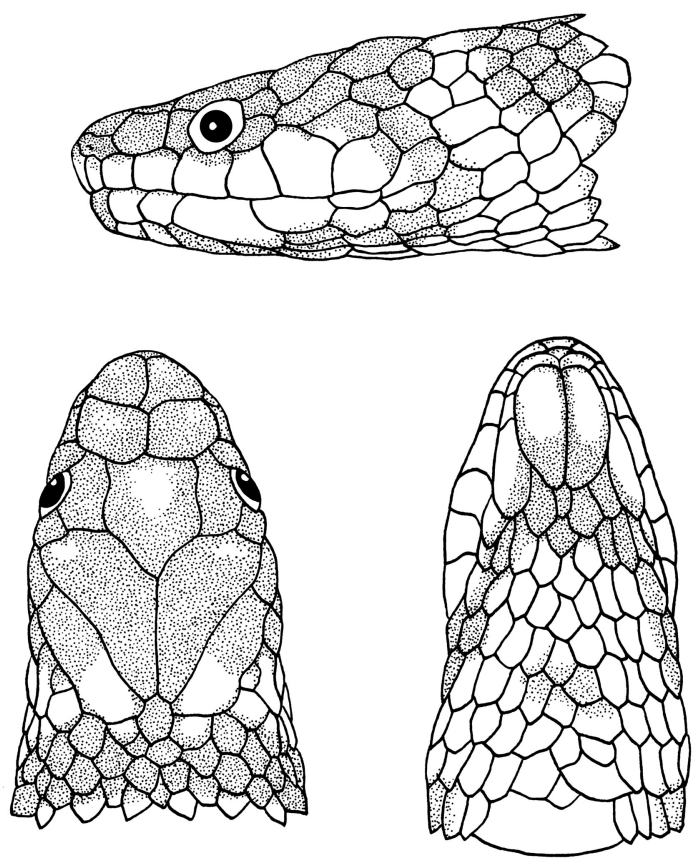

Figure 3. Holotype of Brachyorrhos pygmaeus BMNH1910.4.26.60. Drawings by Nathalie Aall.

fourth enters the orbit, the sixth is the tallest; six lower labials, first four contact the chin shields, the fourth is the longest; eight gulars. Dorsal scales smooth, ovate, and in 20 rows on the anterior body, 19 rows at mid-body and posterior body; ventrals 143, cloacal plate divided, subcaudals 22 and divided.

Coloration in alcohol: Crown red-brown, pale spot on frontal, transverse cream nape band immediately behind parietal scales and interrupted at the parietals by red-brown pigment. Scales above labials red-brown, upper, and lower labials cream except for some red-brown pigmentation on the upper labials under and anterior to the eye. The red-brown pigment extends past the rictus onto the gulars and posterior edges of the chin shields. Isolated spots of red-brown pigment on the posterior gulars, and anterior ventrals. On the right side, a lateral cream stipe on anterior body scale rows $6-8$ starting about the third ventral and continuing to the seventh ventral, on the left side the stripe is much shorter. The ventral surface is mostly a uniform cream with some ventrals having red-brown spots on the edge. The first dorsal scale row is cream; the second row has a central cream spot on each scale edged in red-brown pigment; the same pattern is present on the third row with a much less pale pigment. Dorsal scales above row three are mostly a uniform red brown. The ventral surface of the tail is a uniform cream with a mid-line zig-zag stripe that follows the inner edges of the subcaudal scales.

Table 1 compares this species to other members of the genus.

Etymology: The epithet is derived from the small size of this snake.

Material Examined - Seram: BMNH1910.4.26.60

\section{The Brachyorrhos population on Morotai Island}

A specimen (USNM 159973) collected on the southeast corner of Morotai Island, on 29 September 1944 has a total length of $730 \mathrm{~mm}$, a tail of $71 \mathrm{~mm}, 173$ ventral scales, and 39 subcaudal scales. Rostral and nasal scales visible from above; internasal divided; prefrontal fused with loreal and preocular (a PLP shield); upper labials six; PLP shield contacts upper labials $2-3$; the third upper labial enters the orbit, the fifth upper labial is the tallest; postoculars two, the bottom scale extends under eye; two elongated, very narrow temporals contact postoculars on right, only one of two temporals makes contact on the left; eye diameter less than the eye-mouth distance. This specimen agrees well with Brachyorrhos wallacei from the island of Halmahera nearby located southwest of Morotai, both belonging to North Maluku province. The two islands are separated by an open water channel about $19 \mathrm{~km}$ wide and a trench that reaches a depth of approximately $260 \mathrm{~m}$.

\section{Discussion}

Fangless homalopsids comprise three genera (Brachyorrhos, Calamophis, and Karnsophis) of ten species restricted to Indonesia. All are less than $74 \mathrm{~cm}$ in total length, some are terrestrial, others fossorial and possibly semi-aquatic but all can be regarded as having poorly known life histories; details of microhabitats, diets, reproduction, daily activity all remain unknown. Here we describe the smallest known homalopsid, a fangless species from the island of Seram in Maluku province. We note that its placement in the genus Brachyorrhos is based entirely on morphology, and we cannot rule out the possibility that once molecular data are available it will be assigned to a different lineage.

Table 1 suggests that Brachyorrhos pygmaeus and B. albus share a remarkably similar external morphology, differing in the number of ventrals, a preocular, a loreal, and snout shape. For a perspective on the relationship on the difference in size we measured several near-term embryos of Brachyorrhos albus, which ranged from 136 to $147 \mathrm{~mm}$ in total length. Based on 
Table 1. Summary of some diagnostic characters used to distinguish between the five species of Brachyorrhos.

\begin{tabular}{|c|c|c|c|c|c|}
\hline & $\begin{array}{c}\text { albus } \\
(\mathrm{n}=\mathbf{2 0})\end{array}$ & gastrotaenius $(\mathrm{n}=9)$ & raffrayi $(\mathrm{n}=17)$ & $\begin{array}{l}\text { wallacei } \\
(\mathrm{n}=10)\end{array}$ & $\underset{(\mathrm{n}=1)}{\operatorname{pygmaeus}}$ \\
\hline Distribution & $\begin{array}{c}\text { Ambon, Seram, } \\
\text { Bisa }\end{array}$ & Buru & Ternate & $\begin{array}{c}\text { Halmahera, } \\
\text { Morotai }\end{array}$ & Seram \\
\hline Preocular & present & absent & absent $(65 \%)$ & both & present \\
\hline Loreal & absent & absent & absent & absent & present \\
\hline $\begin{array}{l}\text { Number of upper } \\
\text { labials }\end{array}$ & 7 & 6 & 6 & 7 (rarely 6) & $7 / 6$ \\
\hline $\begin{array}{l}\text { Upper labial in } \\
\text { orbit }\end{array}$ & 4 (rarely $3+4)$ & 4 & 3 & 3 or 4 & 4 \\
\hline $\begin{array}{l}\text { Tallest upper } \\
\text { labial }\end{array}$ & 6 & 5 & 3 & 6 (rarely 5) & 6 \\
\hline Ventrals males & $159-173$ & $177-193$ & $169-177$ & $169-182$ & nd \\
\hline Ventrals females & $171-178$ & $187-195$ & $176-182$ & $170-174$ & 143 \\
\hline Subcaudals males & $26-36$ & $34-37$ & $30-37$ & $33-42$ & nd \\
\hline $\begin{array}{l}\text { Subcaudals } \\
\text { females }\end{array}$ & $23-27$ & $18-29$ & $27-28$ & $26-31$ & 22 \\
\hline Snout & pointed & pointed & very pointed & pointed & rounded \\
\hline Mid-ventral stripe & absent & usually present & absent & absent & absent \\
\hline
\end{tabular}

McDowell's notation accompanying BMNH 1910.4.26.60, B. pygmaeus contained mature ovarian eggs and is therefore sexually mature at a total length of $128 \mathrm{~mm}, 6-9 \mathrm{~mm}$ less than a B. albus embryo. The exceptionally small size of Brachyorrhos pygmaeus makes it a candidate for the world's smallest alethinophidian snake.

The smallest snakes are in the scoleocophidian family Leptotyphlopidae and the smallest known snake is the scolecophidian, Tetracheilostoma carlae (Hedges, 2008) from Barbados (West Indies). The largest known adult is $104 \mathrm{~mm}$. Six leptotyphlopid species have maximum lengths that are less than $105 \mathrm{~mm}$; four are known only from their holotypes (Hedges 2008). However, as noted by Hedges (2008), as species become better known and the number of specimens increases, the maximum size also increases.

Within the alethinophidian snakes, a few species in several lineages approach the diminutive size seen in the scoleocophidians. The highly specialized shield-tailed snakes (Uropletidae) include Uropeltis petersi (Beddome, 1878), a species known to reach $190 \mathrm{~mm}$ in total length, but it is known from only six specimens (Smith 1943; Pyron et al. 2016). There are many small, fossorial colubroid snakes in the $200-300 \mathrm{~mm}$ total length range. Within the Colubroidea, Inger \& Marx (1965) listed 41 species of dwarf reed snakes in the genus Calamaria (Colubridae). Of those, only five species did not exceed 200 $\mathrm{mm}$; and all were represented by less than three individuals. Recently, Koch et al. (2018) described Calamaria banggaiensis Koch, Arida, McGuire, Iskandar \& Böhme, 2009 that has a total length of $199 \mathrm{~mm}$. There are several exceptionally small blackheaded snakes in the genus Tantilla. Savage (2002) reports Tantilla vermiformis (Hallowell, 1861) reaches a maximum length of $157 \mathrm{~mm}$, and it is well represented in collections. The Australian elapid, Simoselaps anomalus (Sternfeld, 1919) reaches a maximum of $210 \mathrm{~mm}$ total length, and S. minimus (Worrell, 1960) reaches $219 \mathrm{~mm}$ (Clarke \& How 1995). In the family Dipsadidae, the Middle American Geophis bellus Myers, 2003 is $210 \mathrm{~mm}$ in total length (Myers 2003). Passos et al. (2009a) described Atractus multidentatus Passos, Rivas Fuenmayor \& Barrio-Amorós, 2009 based upon a single adult female that was $172 \mathrm{~mm}$ in total length from Venezuela's Cordillera de Mérida; later, Passos et al. (2009b) described Atractus avernus Passos, Chiesse, Torres-Carvajal \& Savage, 2009 based upon a single specimen that was $177 \mathrm{~mm}$ in total length. Both species may eventually be found to exceed $200 \mathrm{~mm}$ 
in overall length. The Malagasy Pseudoxyrhopus kely Raxworthy \& Nussbaum, 1994 (Lamprophiidae) has a maximum length of $217 \mathrm{~mm}$ (Glaw \& Vences 2007). The smallest viperid is Bitis schneideri (Boettger, 1886) at $260 \mathrm{~mm}$ maximum length (Mallow et al. 2003). Thus, the smallest, best documented alethinophidian snake is likely Tantilla vermiformis at $157 \mathrm{~mm}$.

The Homalopsidae now includes ten fangless species plus 45 rear-fanged species that are mostly semi-aquatic snakes ranging from the Indus River in Pakistan to the northwest coast of Australia and Micronesia (Vyas et al. 2013; Murphy \& Voris 2013; Quah et al. 2017). Most of the species (37 of 45) occur in South and Southeast Asia, including the larger islands of the Sunda Shelf (Murphy \& Voris 2013; Quah et al. 2017). Of the ten fangless species, only one has been found on the Sunda Shelf (Karnsophis siantaris on Sumatra). These numbers can be expected to change as more species are described and some current taxa are synonymized.

The remaining nine species are restricted to the eastern part of Wallacea, (e.g. North and South Moluccas, Brachyorrhos, 5 species) and on the Sahul Shelf in the Bird's Head region of Papua (Calamophis, 4 species) (Murphy 2012, Murphy et al. 2012). Thus, both the fanged and fangless homalopsids have distributions that extend from South and Southeast Asia, across Wallacea to New Guinea, Australia, and Micronesia. Extant rear-fanged homalopsids were thought to share a common ancestor between 30 and 15 MYA (Alfaro et al. 2008).

However more recent works push homalopsids to older dates of divergence, with Burbrink et al. (2020) suggesting the families Pareidae, Viperidae, and Homalopsidae diverged within the Paleogene. Alfaro et al. (2008) strongly suggest that the fanged homalopsids date to at least the early Miocene or mid to late Oligocene, i.e., 30 to 20 MYA. The results obtained by Alfaro et al. (2008) are not necessarily in opposition to the earlier dates obtained by Harrington \& Reeder (2017) and Burbrink et al. (2020). Tissue from Brachyorrhos (the fangless clade) was not available until 2011 (Murphy et al. 2011). More recently Berstein et al. (2021) obtained a divergence date between the fangless and fanged clade of 43.31 MYA \pm 1.63 MY.

The early Miocene to mid and late Oligocene (20-30 MYA) corresponds closely to when the Australian plate including New Guinea, the Bird's Head, and some fragments of the Malukus (=Moluccas) had moved north to lie adjacent to the southeast edge of the Sunda Shelf (Hall 1996, 2002). Other fragments such as Halmahera were moving west and south towards their present-day location. This scenario suggests homalopsids could have moved from the Sunda Shelf to the
Sahul Shelf in the Oligocene or early Miocene and that the early fangless homalopsids spread from South Asia via the southern edge of the Sunda Shelf to fragments of Wallacea and land components on the Sahul Shelf (Hall 2002, figs. 20, 21; Oliver et al. 2018, fig 2). This scenario also suggests that fangless and semiaquatic rear-fanged homalopsids have spread east from Southeast Asia into Wallacea and Australia in multiple waves during the Paleogene and into the Miocene (Alfaro et al. 2008, Murphy 2011, Berstein et al. 2021).

The movement of both homalopsid clades (rear-fanged and fangless) from Southeast Asia to the Sahul Shelf in the Oligocene or Miocene seems probable, but the family is older than previously thought - with diversification in the Paleogene (Burbrink et al. 2020). Although alternative scenarios have not yet been forth coming based on the revised older dates.

Morphology has been used for centuries to determine relationships of organisms and with the advent of molecular techniques those relationships could be better defined. Brachyorrhos is the only one of three fangless homalopsids represented in phylogenetic studies with molecular data. The other two genera Calamophis and Karnsophis remain poorly known. With advanced techniques of recovering DNA sequences from specimens fixed in formalin, the relationships of these snakes may soon be illuminated using DNA extracted from older, traditional museum specimens (Ruane \& Austin 2017).

\section{Acknowledgements}

At the Field Museum (FMNH) we would like to thank Alan Resetar for lab space and logistical support. For the loan of specimens or access to museum collections, we thank Colin McCarthy at the British Museum of Natural History (MNH), London; and Rob Wilson and W. Ron Heyer at the National Museum of Natural History (USNM). We also thank Nathalie Aall for her illustrations of Brachyorrhos pygmaeus; and Harry Greene, Laurie Vitt, and Van Wallach for advice on the smallest alethinophidian snakes.

\section{Literature Cited}

Alfaro, M.E., D.R. Karns, H.K. Voris, C.D. Brock, \& B.L. Stuart, 2008. Phylogeny, evolutionary history, and biogeography of oriental-Australian rear-fanged water snakes (Colubroidea: Homalopsidae) inferred from mitochondrial and nuclear DNA sequences. Molecular Phylogenetics and Evolution, 46: 576-593.

Bernstein, J.M., J.C. Murphy, H.K, Voris, R.M. Brown, S. Ruane. 2021. Phylogenetics of mud snakes (Squamata: 
Serpentes: Homalopsidae): A paradox of both undescribed diversity and taxonomic inflation. Molecular Phylogenetics and Evolution, 160:107109.

Burbrink, F.T., F.G. Grazziotin, R.A. Pyron, D. Cundall, S. Donnellan, F. Irish, J.S. Keogh, F. Kraus, R.W. Murphy, B. Noonan, \& C.J. Raxworthy, 2020. Interrogating genomicscale data for Squamata (lizards, snakes, and amphisbaenians) shows no support for key traditional morphological relationships. Systematic Biology, 69(3): 502 $-520$.

Clarke, V. \& R.A. How, 1995. Body dimensions in Simoselaps and Vermicella (Elapidae): a method for determining sex in natural populations. Records of the Western Australian Museum, 17: 69-72.

Dowling, H.G. 1951. A proposed standard system of counting ventrals in snakes. British Journal of Herpetology, 1: 9799.

Glaw F. \& M. Vences. 2007. A Field Guide to the Amphibians and Reptiles of Madagascar Vences \& Glaw Verlags GbR, Cologne, Germany. 495 pp.

Harrington, S.M. \& T.W. Reeder, 2017. Phylogenetic inference and divergence dating of snakes using molecules, morphology, and fossils: new insights into convergent evolution of feeding morphology and limb reduction. Biological Journal of the Linnean Society, 121(2): 379394.

Hall, R., 1996. Reconstructing Cenozoic SE Asia, Pages 153184 in: Hall, R. \& B. Lundell, Tectonic Evolution of Southeast Asia. Geological Society Special Publication no. 106. xiii 566 pp. Bath, London.

Hall, R. 2002. Cenozoic geological and plate tectonic evolution of SE Asia and the SW Pacific: computer-based reconstructions, model, and animations. Journal of Asian Earth Sciences, 2: 353-431.

Hedges, S.B., 2008. At the lower size limit in snakes: two new species of threadsnakes Squamata: Leptotyphlopidae: Leptotyphlops) from the Lesser Antilles. Zootaxa, 1841:130.

Inger, R.F. \& H. Marx. 1965. The systematics and evolution of the Oriental colubrid snakes of the genus Calamaria. Fieldiana: Zoology, 49: 1-304.

Koch A., E. Arida, J.A. McGuire, D.T. Iskandar \& W. Böhme. 2018. A new species of Calamaria (Squamata: Colubridae) similar to C. ceramensis de Rooij, 1913, from the Banggai Islands, east of Sulawesi, Indonesia. Zootaxa, (2196): 1930.

LeCroy, M. 2003. Type specimens of birds in the American Museum of Natural History. Part 5. Passeriformes: Alaudidae, Hirundinidae, Motacillidae, Campephagidae,
Pycnonotidae, Irenidae, Laniidae, Vangidae, Bombycillidae, Dulidae, Cinclidae, Troglodytidae, and Mimidae. Bulletin of the American Museum of Natural History, (278): 1-156.

Lily, M. 2008. Type specimens of birds in the American Museum of Natural History. Part 7. Passeriformes: Sylviidae, Muscicapidae, Platysteiridae, Maluridae, Acanthizidae, Monarchidae, Rhipiduridae, and Petroicidae. Bulletin of the American Museum of Natural History, (313): $1-288$.

Lillywhite, H.B. 2008. Dictionary of Herpetology. Krieger Publishing, Malabar, FL 376 pp.

Linnaeus, C. 1758. Systema Naturae per Regna Tria Naturae, Secundum Classes, Ordines, Genera, Species, cun Characteribus, Differentiis, Synonymis, Locis. Editio Decima $\left(10^{\text {th }}\right.$ ed.). Volume 1. Laurenti Salvi. Holimiae (Stockholm) $824 \mathrm{pp}$.

Mallow D., D. Ludwig, \& G. Nilson. 2003. True Vipers: Natural History and Toxinology of Old World Vipers. Krieger Publishing Company, 359 pp.

McDowell, S.B., 1987. Systematics. Pages 3-50, in: Snakes, Ecology and Evolutionary Biology. Seigel, R.A., Collins, J.T., Novak, S.S. (eds.). McGraw-Hill Publishing Co., New York.

Meyer, A.B., 1874. Übersicht der von mir auf Neu-Guinea und den Inseln Jobi, Mysore und Mafoor im Jahre 1873 gesammelten Amphibien. Monatsberichte der Preussischen Akademie der Wissenschaften zu Berlin, 1874: 128-140.

Myers, C.W., 2003. Rare snakes-five new species from eastern Panama: reviews of northern Atractus and southern Geophis (Colubridae: Dipsadinae). American Museum Novitates, (3391): 1-47.

Murphy, J.C., 2011. The nomenclature and systematics of some Australasian homalopsid snakes (Squamata: Serpentes: Homalopsidae). The Raffles Bulletin of Zoology, 59: 229236.

Murphy, J.C., 2012. Synonymized and forgotten, the Bird's Head stout-tailed snakes, Calamophis Meyer (Squamata, Serpentes, Homalopsidae). The Raffles Bulletin of Zoology, 60(2): 515-523.

Murphy, J.C, Mumpuni \& K.L. Sanders, 2011. First molecular evidence for the phylogenetic placement of the enigmatic snake genus Brachyorrhos (Serpentes: Caenophidia). Molecular Phylogenetics and Evolution, 61(3):953-957.

Murphy, J.C., R. De Lang, D.J. Gower, \& K.L. Sanders, 2012. The Moluccan short-tailed snakes of the genus Brachyorrhos Kuhl (Squamata: Serpentes: Homalopsidae), and the status of Calamophis Meyer. The Raffles Bulletin of Zoology, 60: 501-514.

Murphy, J.C. \& H.K. Voris, 2013. An unusual, fangless short- 
tailed snake (Squamata, Serpentes, Homalopsidae) from Sumatra, Indonesia. Asian Herpetological Research, 4: 140 -146 .

Murphy, J.C. \& H.K. Voris, 2014. A checklist and key to the homalopsid snakes (Reptilia, Squamata, Serpentes), with the description of new genera. Fieldiana Life and Earth Sciences, (1567): 1-43.

Oliver P.M, R.M. Brown, F. Kraus, E. Rittmeyer, S.L. Travers, \& C.D. Siler, 2018. Lizards of the lost arcs: mid-Cenozoic diversification, persistence and ecological marginalization in the West Pacific. Proceedings of the Royal Society B Biological Sciences, 285: 20171760.

Passos, P., G. Rivas Fuenmayor, \& C. Barrio-Amorós, 2009a. Description of two new species from Venezuela in the highly diverse dipsadine genus Atractus (Serpentes: Colubridae). Amphibia-Reptilia, 30: 233-243.

Passos, P., A. Chiesse, O. Torres-Carvajal, \& J.M. Savage, 2009b. Testing species boundaries within the Atractus occipitoalbus complex (Serpentes: Dipsadidae). Herpetologica, 65: 384-403.

Peters, W. \& G. Doria, 1878. Catalogi dei rettili e dei batraci. Annali del Museo Civico di Storia Naturale di Genova, 13: 323-450.

Pyron, R.A., S.R. Ganesh, A. Sayyed, V. Sharma, V. Wallach, \& R. Somaweera, 2016. A catalogue and systematic overview of the shield-tailed snakes (Serpentes: Uropeltidae). Zoosystema, 38: 453-507.

Quah E.S., L.L. Grismer, P.L. Wood, M.K. Thura, T. Zin, H. Kyaw, N. Lwin, M.S. Grismer, \& M.L. Murdoch, 2017. A new species of mud snake (Serpentes, Homalopsidae, Gyiophis Murphy \& Voris, 2014) from Myanmar with a first molecular phylogenetic assessment of the genus. Zootaxa, 4238: 571-82.

Rabb, G.B. \& H. Marx, 1973. Major ecological and geographic patterns in the evolution of colubroid snakes. Evolution, 1973: 69-83.

Ruane, S. \& C.C. Austin. 2017. Phylogenomics using formalinfixed and $100+$ year-old intractable natural history specimens. Molecular Ecology Resources, 17: 1003-1008.

Sauvage, M.H.-E., 1878 (1879). Sur un Rhabdosomien de genre nouveau provenant de Ternate. Bulletin Société philomathique de Paris, 3: 61-63.

Savage, J., 2002. The Amphibians and Reptiles of Costa Rica, A Herpetofauna between Two Seas. University of Chicago Press, Chicago. 934 pp.

Savitzky, A.H., 1983. Coadapted character complexes among snakes: fossoriality, piscivory, and durophagy. American Zoologist, 23: 397-409.

Schlegel, H., 1826. Notice sur l'erpétologie de l'ile de Java: par
M. Böié (Ouvrage manuscript). Bulletin des Sciences Naturelles et de Géologie, 9: 234-240.

Vyas, R.V., J.C. Murphy, \& H.K. Voris, 2013. The dog-faced water snake (Cerberus rynchops) and Gerard's mud snake (Gerarda prevostiana) at the western edge of their distribution. Herpetological Review, 44: 34-36.

Wollaston, A.F.R., 1912. Pygmies and Papuans, The Stone Age Today in Dutch New Guinea. Sturgis and Walton Company, New York. 352 pp. 
Appendix 1. Material examined. Brachyorrhos albus - Ambon: Waai- -FMNH 134322-24, 142332, 142145-46; MZB 1524A-B No specific locality-MSNG30192a; Seram: Honititoe -FMNH 109949, 119654; BMNH 442222, 6312425; Saunulu -MZB2364; RMNH 576; ZMA 10494(2); ZMA10104(2). Pulau Bisa - MZB2609. Brachyorrhos gastrotaenius "Ambonia" (probably in error see comments) -BMNH6312425; Buru - Fakal: ZMA13.044(3); Rana - ZMA12.844(3). Brachyorrhos pygmaeus - Seram: BMNH1910.4.26.60. Brachyorrhos raffrayi - Ternate: BMNH82.11.25.14, and 48.1.31.10; MNHN 5174, 5782 and 1991.1657; MSNG30222a-f, 54459-62; MZB T128, T099. Brachyorrhos wallacei - Halmahera: Jailolo MZB-BJE01059 MZB-BJE01054, MZB-BJE01058; Kampung PasirPatih-USNM 237145-150; Sidangoli- MZB2111; Weda Bay Mines- MZB-WD0128. 
Appendix 2. Details of PCA.

\begin{tabular}{llll}
\hline & PC & \% Variation & Total Variation \\
\hline 1 & T/SVL & 44.03 & 44.03 \\
2 & ventrals & 17.15 & 61.18 \\
3 & subcaudals & 12.81 & 74.00 \\
4 & DSR & 10.31 & 83.30 \\
5 & postocular & 6.34 & 90.64 \\
6 & upper labials & 4.85 & 95.49 \\
7 & upper labials in orbit & 2.47 & 97.96 \\
8 & tallest upper labial & 1.26 & 99.22 \\
9 & internasal & 0.58 & 99.80 \\
10 & loreal & 0.20 & 100.00 \\
11 & premaxillary & 0.00 & 100.00 \\
12 & jaw counter sunk & 0.00 & 100.00 \\
\hline
\end{tabular}

